\title{
Forced Labour and Human Trafficking: Estimating the Profits
}

\section{Patrick Belser}


WP. 42

Working Paper

\section{Forced Labour and Human Trafficking: Estimating the Profits}

by Patrick Belser

International Labour Office

Geneva

March 2005 
Publications of the International Labour Office enjoy copyright under Protocol 2 of the Universal Copyright Convention. Nevertheless, short excerpts from them may be reproduced without authorization, on condition that the source is indicated. For rights of reproduction or translation, application should be made to the Publications Bureau (Rights and Permissions), International Labour Office, CH-1211 Geneva 22, Switzerland. The International Labour Office welcomes such applications.

Libraries, institutions and other users registered in the United Kingdom with the Copyright Licensing Agency, 90 Tottenham Court Road, London W1T 4LP [Fax: (+44) (0)20 7631 5500; email: cla@cla.co.uk], in the United States with the Copyright Clearance Center, 222 Rosewood Drive, Danvers, MA 01923 [Fax: (+1) (978) 750 4470; email: info@copyright.com] or in other countries with associated Reproduction Rights Organizations, may make photocopies in accordance with the licences issued to them for this purpose.

ISBN 92-2-117304-6

First published 2005

The designations employed in ILO publications, which are in conformity with United Nations practice, and the presentation of material therein do not imply the expression of any opinion whatsoever on the part of the International Labour Office concerning the legal status of any country, area or territory or of its authorities, or concerning the delimitation of its frontiers.

The responsibility for opinions expressed in signed articles, studies and other contributions rests solely with their authors, and publication does not constitute an endorsement by the International Labour Office of the opinions expressed in them.

Reference to names of firms and commercial products and processes does not imply their endorsement by the International Labour Office, and any failure to mention a particular firm, commercial product or process is not a sign of disapproval.

ILO publications can be obtained through major booksellers or ILO local offices in many countries, or direct from ILO Publications, International Labour Office, CH-1211 Geneva 22, Switzerland. Catalogues or lists of new publications are available free of charge from the above address, or by email: pubvente@ilo.org

Visit our website: www.ilo.org/publns 


\section{Foreword}

In June 1998 the International Labour Conference adopted a Declaration on Fundamental Principles and Rights at Work and its Follow-up that obligates member States to respect, promote and realize freedom of association and the right to collective bargaining, the elimination of all forms of forced or compulsory labour, the effective abolition of child labour, and the elimination of discrimination in respect of employment and occupation. ${ }^{1}$ The InFocus Programme on Promoting the Declaration is responsible for the reporting processes and technical cooperation activities associated with the Declaration; and it carries out awareness raising, advocacy and knowledge functions - of which this Working Paper is an example. Working Papers are meant to stimulate discussion of the questions covered by the Declaration. They express the views of the author, which are not necessarily those of the ILO.

As part of ILO activities to promote the Declaration, a Special Action Programme to combat Forced Labour (SAP-FL) was created by the ILO Governing Body in November 2001. Since then, SAP-FL's work has included research, awareness raising and technical cooperation, working with governments, employers, workers and others to abolish forced labour. And in all of these activities, particular attention has been given to the forced labour outcomes of human trafficking.

This Working Paper's objective is to estimate the magnitude of global profits that are being realized through the exploitation of forced labourers. The paper is thus part of SAP-FL research on the quantitative and economic dimensions of forced labour and human trafficking. This analysis complements other research published by SAP-FL, in particular on the economic perspective on human trafficking in Europe (Working Paper No.31) and on the definition, indicators and measurement of forced labour (Working Paper No. 18). The calculations in the present analysis also use the result of another important piece of research, namely the calculation of a minimum estimate of forced labour in the world. Both the global minimum estimate and some of the figures calculated in this Working Paper are included in the ILO Director General's 2005 Global Report on forced labour.

The paper's main estimate is that global profits made from forced labourers exploited by private enterprises or agents reach US\$ 44.3 billion every year, of which US\$ 31.6 billion from trafficked victims. The largest profits - more than US\$ 15 billion - are made from people trafficked and forced to work in industrialized countries. These figures show that profits are possibly much larger than has so far been recognized in the estimates of other national or international organizations. They also support the view that trafficking thrives because it is lucrative and that policy measures to combat this scourge must include the confiscation of the financial assets of those involved in trafficking across or within borders.

I thank Mr. Belser for undertaking this experimental assignment and hope that this analysis will be heard and debated. I also hope that it will help to raise awareness and contribute to mobilize the world against forced labour and human trafficking.

Roger Plant

Head, Special Action Programme to Combat Forced Labour

InFocus Programme on Promoting the Declaration

\footnotetext{
${ }^{1}$ The text of the Declaration is available on the following web site: http://www.ilo.org/declaration
} 


\section{Table of Contents}

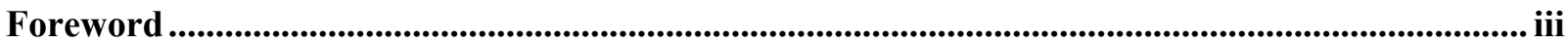

Acknowledgements ................................................................................................................................................ vii

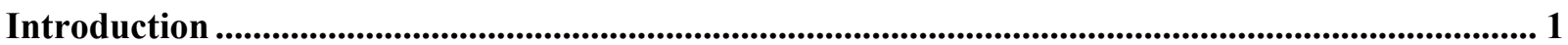

1. Forced labour: definition, forms and magnitude..................................................................... 2

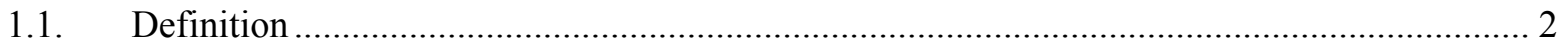

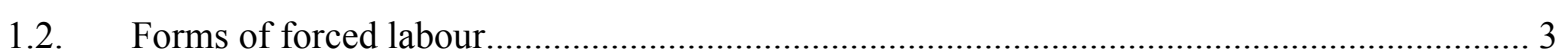

1.3. The ILO's Global Estimate of Forced Labour: a summary ….............................................. 4

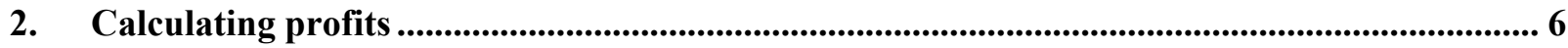

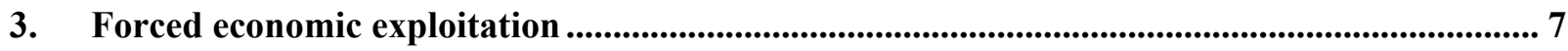

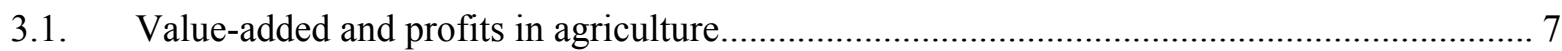

3.2. Average value-added in low-skilled activities ................................................................ 10

3.3. Estimating the profits from forced economic exploitation ................................................ 11

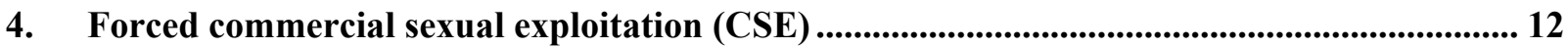

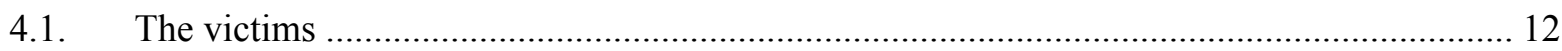

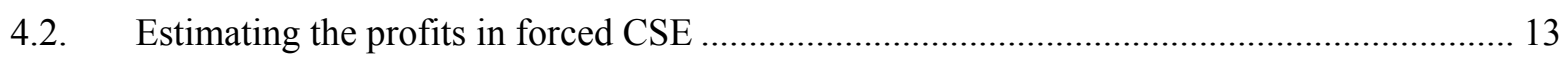

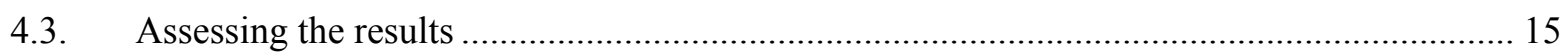

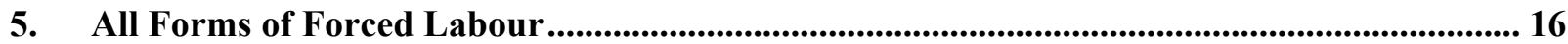

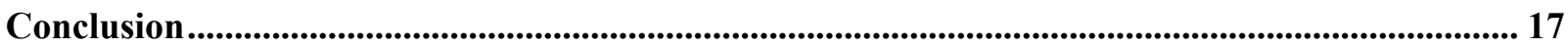

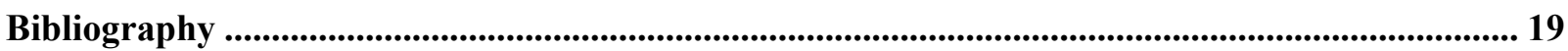

List of Working Papers of the InFocus Programme on Promoting the Declaration......................... 21 


\section{Acknowledgements}

I wish to thank Akshay Garg and Nitya Mohan for their excellent research assistance and the many data they have collected from a large number of sources. I also wish to thank Caroline O'Reilly, Farhad Mehran, David Kucera, Roger Plant, Zafar Shaheed and Lee Swepston for their very useful comments and suggestions. 



\section{"To put into words is to find the hope that the words will be heard and the events they describe judged". \\ John Berger, The Sense of Sight, 1985}

\section{Introduction}

In April 2003, The New Yorker magazine ${ }^{2}$ ran a vivid story of modern forced labour. Three young Mexicans had contracted a smuggler, a so-called "coyote", to cross illegally into the U.S. They were transported through Arizona into Florida, where they were introduced to some labour contractors the Ramos brothers. The three Mexicans were ordered to pay a commission of US $\$ 1,000$ each to the smugglers for connecting them with the labour contractors. Since none of the three could pay, the Ramos brothers pretended to advance the sum to the smugglers and informed the Mexicans they would have to work to pay the money back. The next day, the three friends were picking tomatoes and citrus under constant surveillance and threats for eight to twelve hours a day, for six to seven days a week, and for almost no money. This situation lasted until an NGO helped the workers to escape.

In March 2004, The Guardian ${ }^{3}$ ran a short story about modern debt bondage in Europe. South African workers had been contracted by a British employment agency that promised high salaries in the U.K. The workers thus entered into an agreement with a travel agency in Pretoria, which loaned them $£ 1,500$ for applying for a two-year working visa and to pay for their flights. The workers agreed to repay the loan in 12 weeks at $100 \%$ interest. Once in the U.K., the workers realized that the agency deducted from their pay not only the interest on the loan but also exaggerated rents for small and crowded rooms, and high administrative charges for each shift. Most workers were left with hardly anything to live and were unable to pay back their debt. The South African workers were being supplied at an extraordinarily low hourly rate to one of the largest fruit packers in the country.

In his recently published book called The Natashas, Victor Malarek (2003) reminds us that prostitution is a major area of forced labour. Malarek recounts the story of Marika, a young unemployed woman from Ukraine. In her hometown, a recruitment agency told her that it had arranged a job as a waitress in Tel Aviv. She flew to Cairo, from where Bedouins transported her across the desert into Israel. Marika ended up in an apartment near the sea, with three other women. The doors were locked and a guard stood in the hallway. A man announced that he had purchased her for $\$ 10,000$ and that she would have to work as a prostitute until she had paid off a $\$ 20,000$ debt. Over four months she then serviced - according to Malarek's account - hundreds of "soldiers, husbands, and religious men".

Finally, a column published in India's national magazine Frontline ${ }^{4}$ in January 2003 illustrates the persistence of more traditional forms of forced labour in developing countries. The column tells the story of Gopinath Dura, a "bonded slave for more than 40 years to one master" in the Indian state of Orissa. His father gave him away to a rich moneylender at age 5 to repay a loan. Since then, Gopinath has slept in his master's courtyard, worked on his fields, tended his cattle and attended every day to domestic chores in his home. He was paid three bags of paddy every year after each harvest - but the master immediately took back the paddy into his own store bags, explaining that Gopinath anyway eats all his meals from the master's kitchen. "Apart from two sets of clothes annually, Gopinath sometimes is given two or three rupees as a treat. He spends this to buy bidis ${ }^{5}$, his only occasional indulgence".

All four cases illustrate the reality of contemporary forced labour. Three of the cases also reflect modern human trafficking, where people are being transported across or within borders before being forced to work. The last case illustrates a type of forced labour which is rooted in discrimination and

\footnotetext{
2 John Bowe, Nobodies: Does slavery exist in America? The New Yorker, April 21 \& 28, 2003, p. 106

${ }^{3}$ Felicity Lawrence, Migrants in bonded labour trap, The Guardian, March 29, 2004

${ }^{4}$ Harsh Mander, In bonded servitude, Frontline, January 18-31, 2003, Vol. 20 - Issue 02.

${ }^{5}$ Hand-rolled cigarettes
} 
unequal social relations. What all the cases have in common, though, is the economic exploitation of the victims, who are paid little or no money, thus raising the material welfare of the perpetrators. In fact, this economic exploitation is probably the motivation behind most cases of forced labour. If it were not for lower labour costs and higher profits, why would anyone turn to the use of forced labour? If there were no intention to exploit the work of labourers, why not simply recruit voluntary labourers at market wages? As emphasized by economist Paul Krugman, "there is no point in enslaving or enserfing a man unless the wage you would have to pay him if he was free is substantially above the cost of feeding, housing, and clothing him". ${ }^{6}$

The present paper's objective is to estimate the global magnitude of forced labour profits in order to throw light on the scale of this economic exploitation. To paraphrase John Berger (1985): to put into numbers is to find the hope that the numbers will be heard and that the problem will be acted upon. The paper is organized as follows. The first section defines forced labour, describes its main forms and summarizes the ILO's global minimum estimate of forced labour in the world. This global estimate is of course a key building block in estimating the profits. It would be very difficult to estimate profits without an estimate of how many people are in forced labour. The second section briefly explains what is meant by profits and how they can be calculated. In the third section, we calculate the profits made from forced labour in agriculture and other non-sexual activities. This includes an estimation of the profits from the "labour dimension" of human trafficking. In the fourth section, we estimate the profits made with forced commercial sexual exploitation - both with trafficked and nontrafficked victims. The last section brings together the estimates from the previous sections and aggregates the total profits of forced labour and human trafficking.

\section{Forced labour: definition, forms and magnitude ${ }^{7}$}

\subsection{Definition}

What is forced labour? ILO Convention No. 29 (1930) defines forced or compulsory labour as "all work or service which is exacted from any person under the menace of any penalty and for which the said person has not offered himself voluntarily" (Art.2.1). The Convention provides for certain exceptions, in particular with regard to military service for work of purely military character, normal civic obligations, work of prisoners convicted in a court of law and working under the control of a public authority, work in emergency cases such as wars or other calamities, and minor communal services (Art. 2.2). A subsequent ILO Convention No. 105, adopted in 1957, specifies that forced labour can never be used for the purpose of economic development or as a means of political education, discrimination, labour discipline or punishment for having participated in strikes.

From this definition it is clear that forced labour is not just equivalent to low wages or poor working conditions. It represents a restriction in human freedom, a violation of human rights, and the exact opposite of "decent work" or "human development" as defined by the ILO and UNDP, respectively. Forced labour also encompasses situations such as slavery, practices similar to slavery, debt bondage, or serfdom as defined in various international instruments. ${ }^{8}$ Embedded in the international definition of forced labour are two essential criteria: the "menace of penalty" and the "involuntariness". Accordingly, forced labour occurs when people are being subjected to psychological and/or physical coercion (the menace of a penalty) in order to perform some work or service which they would otherwise not have accepted, or not have accepted at the prevailing conditions (the involuntariness). The work of the ILO's supervisory bodies makes it clear that the consent of workers is

\footnotetext{
${ }^{6}$ This is quoted from the text published on the official Paul Krugman web page on 05.08.2003

${ }^{7}$ This section draws heavily on the ILO Global Report (2005) and on Belser, de Cock and Mehran (2005) where the ILO minimum estimation of forced labour in the world is described in more details.

${ }^{8}$ See in particular the League of Nations' Slavery Convention (1926) for the definition of slavery, and the UN Supplementary Convention on the Abolition of Slavery, the Slave Trade and Institutions and Practices Similar to Slavery (1956) for the definition of debt bondage and serfdom.
} 
irrelevant when there has been deception or fraud, or the retention of identity documents in order to achieve this consent. ${ }^{9}$

In practice, many victims enter into forced labour through fraud and deception. The menace of a penalty that follows is often in the form of physical violence or death threats addressed to the victim or his or her family. The penalty can also be in the form of denunciation to the police or immigration authorities when the victims' residence or work status is illegal, of confiscation of identity papers, or even of supernatural retaliation. The non-payment of wages can also be used as a way to "blackmail" workers into providing involuntary labour. In principle, when trying to determine whether a person is in forced labour, both the penalty and involuntariness criteria should be verified. Yet, in practice, if there is a menace of penalty there is normally also a lack of free choice.

It is worth emphasizing that it is the type of engagement that links a person to an "employer" which determines forced labour, not the type of activity that a worker is actually performing. A woman trafficked and forced into prostitution is in forced labour because of the menace under which she is working, not because of the sexual duties that her job demands or the legality or illegality of that particular occupation. In some cases, the activity itself may not be an economic activity as understood within the framework of national accounts. It is also worth noting that not all child labour is considered as forced labour. In the estimate, child labour has only been counted as forced labour when coercion is applied by a third party to the children or to the parents of the children, or when a child's work is the direct result of the parents being in forced labour.

\subsection{Forms of forced labour}

For the purpose of estimating the magnitude of forced labour, the ILO has created a simple typology with three broad forms of forced labour:

- Forced labour imposed by the State or by armed forces - which includes three main sub-categories, namely forced labour exacted by the military or by rebel groups, compulsory participation in public works, and forced prison labour.

- Forced commercial sexual exploitation (CSE), which includes women, men and children who have been forced by private agents into prostitution or into other forms of commercial sexual activities.

- Forced labour for economic exploitation (EE), which comprises all forced labour imposed by private agents and enterprises ${ }^{10}$ in sectors other than the sex industry. It includes forced labour in agriculture, industry, and services, as well as in some illegal activities.

In this paper, we consider the profits extracted from the last two types outlined above. In addition to this broad typology, a distinction was drawn between forced labourers who were trafficked and forced labourers who were not trafficked. In recent years, there has been a growing awareness of human trafficking as a form of modern slavery and as a threat to human security (see, for example, FukudaParr, 2003). The U.S. Department of State has identified trafficking in persons as "one of the greatest human rights challenges of our time" $\left(2003\right.$, p.5). Human trafficking is defined by the United Nations ${ }^{11}$ as the recruitment or transfer of persons, by force, abduction or deception, for the purpose of "exploitation". The U.N. further specifies that "exploitation" includes "forced labour or services, slavery, or practices similar to slavery" as well as other things - which are not the subject of the present paper - such as "the removal of organs".

\footnotetext{
${ }^{9}$ This paper refers only to illicit forced labour. Some forms of compulsion are allowed by international standards, such as compulsory military service, civic duties, and prison labour under conditions laid down in the Forced Labour Convention, 1930 (No. 29).

${ }^{10}$ Enterprises are defined here broadly as institutional units, such as persons or groups of persons or other entities, in their capacity as economic production units (see OECD et al., 2002).

${ }^{11}$ See the UN Protocol to Prevent, Suppress, and Punish Trafficking in Persons, Especially Women and Children (the socalled Palermo Protocol).
} 


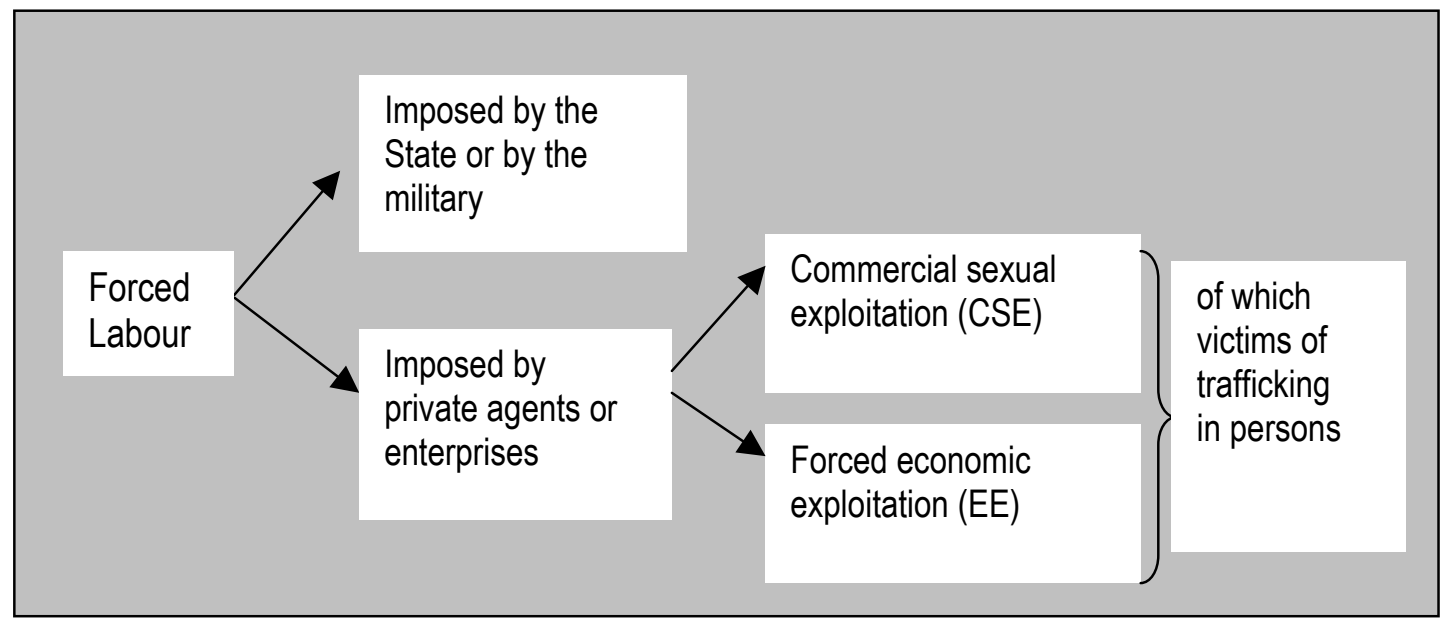

Source : Global Report, ILO, 2005

\subsection{The ILO's Global Estimate of Forced Labour: a summary}

The ILO's latest Global Report on forced labour (ILO, 2005) published the results of a minimum estimation of forced labour in the world. Both the methodology and the results of this global estimate were explained in details in another document (Belser, de Cock, Mehran, 2005). They are briefly summarized here.

The methodology has two steps. First, a statistical methodology is used to estimate the number of cases of forced labour - and the total number of victims - which have been reported during 19952004 by international organisations, governments, unions, tribunals, the police, academia, nongovernmental organisation, the press and other sources. Information on the number of victims, their location, their personal characteristics, and their activities was collected in many different languages ${ }^{12}$ and stored in a database. Secondly, the estimate of reported cases is used to derive an estimate of the actual number of people in forced labour at the present time.

With this method, the ILO found that there are at least 12.3 million people in forced labour worldwide. Of these 12.3 million, there are 2.5 million people who are forced to work by the state, the army or rebel military groups. The focus of the present paper is on the remaining 9.8 million people who are exploited by private agents and enterprises. Of these, the ILO calculates that about 1.4 million are in forced commercial sexual exploitation (CSE) and 7.8 million are in forced economic exploitation (EE). In addition, in the ILO estimate, more than half a million victims could not be assigned unambiguously to one or the other category (see table 1). If we assume that undetermined victims are distributed evenly across both categories, we find that there are about 1.7 million in commercial sexual exploitation (CSE) and 8.1 million in other economic exploitation (EE).

${ }^{12}$ Arabic, English, French, German, Hindi, Italian, Portuguese, Russian, and Spanish. 


\section{Figure 2: $\quad$ Forced Labour by Form}

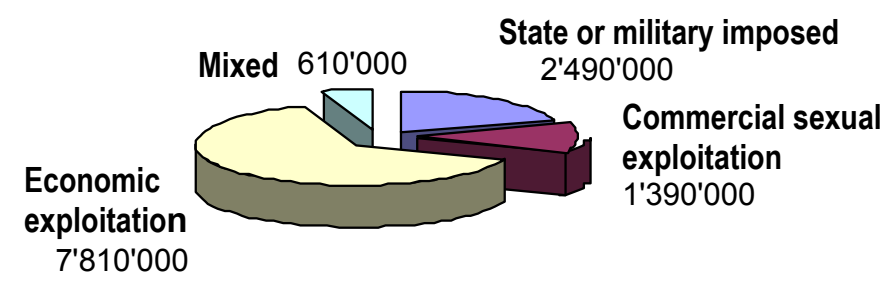

Source : Global Report, ILO, 2005

Table 1: Total Forced Labour imposed by Private Agents and Enterprises

\begin{tabular}{|lcccc|}
\hline & $\begin{array}{c}\text { Forced commercial } \\
\text { sexual exploitation }\end{array}$ & $\begin{array}{c}\text { Forced economic } \\
\text { exploitation }\end{array}$ & $\begin{array}{c}\text { Mixed or } \\
\text { undetermined }\end{array}$ & Total \\
\hline Industrialized Economies & 200,000 & 84,000 & 58,000 & 342,000 \\
Transition Economies & 98,000 & 10,000 & 103,000 & 211,000 \\
Asia \& Pacific & 902,000 & $5,964,000$ & 434,000 & $7,300,000$ \\
Latin America \& Caribbean & 115,000 & 994,000 & 3,000 & $1,112,000$ \\
Sub-Saharan Africa & 50,000 & 531,000 & 13,000 & 594,000 \\
MENA $^{13}$ & 25,000 & 229,000 & - & 254,000 \\
\hline World & & & & \\
\hline
\end{tabular}

Source: Belser, de Cock, Mehran (2005)

The ILO found that almost 2.5 million people who are exploited by private agents and enterprises are in forced labour as a result of human trafficking. This includes not only international cross-border trafficking, but also internal trafficking within a country's own border. Of these 2.5 million, it has been calculated that about 1.1 million are in commercial sexual exploitation (CSE), 800,000 are in other economic exploitation (EE), and 600,000 are undetermined (see table 2). If we again assume that half of the undetermined victims are distributed in each of the two categories, we find that there are about 1.4 million in commercial sexual exploitation (CSE) and 1.1 million in other economic exploitation (EE). Thus, contrary to forced labour in general, more than half of trafficking is for forced sexual exploitation. However, trafficking is not exclusively a "sex issue". With more than 40 percent of cases, "the labour dimension of trafficking" also represents a large share of all cases. In table 2 , the first three columns indicate for each region the estimated share of the various forms of exploitation in total forced labour.

Of course, all these results must be treated with caution. The reliability of the figures unavoidably reflects the quality and the quantity of available information and, like all estimates, is subject to sampling and other errors. In particular, there is a large degree of uncertainty about the real extent of forced labour in South Asia, and especially in India. Also, the breakdown by form within each region is less reliable than the overall global estimate. Overall, however, the estimate is more likely to be an underestimate of the true scale of forced labour than an exaggeration.

\footnotetext{
${ }^{13}$ MENA refers to Middle East and North Africa
} 
Table 2: Total Trafficking-related Forced Labour

\begin{tabular}{|lcccc|}
\hline & $\begin{array}{c}\text { Forced } \\
\text { commercial sexual } \\
\text { exploitation }\end{array}$ & $\begin{array}{c}\text { Forced } \\
\text { economic } \\
\text { exploitation }\end{array}$ & $\begin{array}{c}\text { Mixed or } \\
\text { undetermined }\end{array}$ & Total \\
\hline Industrialized Economies & $63 \%$ & $17 \%$ & $20 \%$ & 270,000 \\
Transition Economies & $45 \%$ & $4 \%$ & $50 \%$ & 200,000 \\
Asia and the Pacific & $54 \%$ & $14 \%$ & $32 \%$ & $1,360,000$ \\
Latin America \& Caribbean & $12 \%$ & $87 \%$ & $1 \%$ & 250,000 \\
Sub-Saharan Africa & $6 \%$ & $84 \%$ & $7 \%$ & 130,000 \\
MENA & $10 \%$ & $89 \%$ & $1 \%$ & 230,000 \\
\hline World & $1,060,000$ & 780,000 & 600,000 & $2,440,000$ \\
\hline
\end{tabular}

Source: Belser, de Cock, Mehran (2005)

\section{Calculating profits}

How can we calculate the profits made by criminal agents and enterprises that use forced labour? As shown in equation [1], total profits $(\pi)$ can be broadly defined as the total economic valueadded (VA) minus total wage payments (W). ${ }^{14}$

$$
\pi=\mathrm{VA}-\mathrm{W}
$$

In the case of forced labour, wages are usually below market rates and many victims are paid just enough for their subsistence. In the most extreme cases, traffickers and other perpetrators have complete discretion over the payments to forced labourers. Hence, it is difficult to consider whatever payment the victims receive as a "wage" in its standard definition, i.e. the compensation obtained by voluntary workers in the labour market. This, however, does not change the fact that the expenditures for the subsistence of workers reduce the profits of the perpetrators and, hence, must be deducted from value-added. Thus, whenever possible, we use equation [1] to estimate profits.

If data on value-added is not available, profits can be estimated by using information on turnover and intermediate expenditures. Equation [1] can be rewritten as shown in equation [2], where profits $(\pi)$ are equal to the difference between the total turnover $(\mathrm{T})$ - i.e. the total value of goods or services produced - and the sum of wage payments $(\mathrm{W})$ and intermediate consumption $(\mathrm{C})$, which is the expenditure for all necessary inputs, such as rent for example.

$$
\pi=\mathrm{T}-(\mathrm{W}+\mathrm{C})
$$

As shown in equation [3], turnover (T) is equal to the number of workers $(\mathrm{N})$ multiplied by the average value of the goods and services produced by each worker $(\mathrm{t})$ - which is itself equal to the physical number of units of goods or services produced by each worker (q) multiplied by the average price of the goods or services produced (p).

$$
\mathrm{T}=\mathrm{t} \cdot \mathrm{N}=(\mathrm{q} \cdot \mathrm{p}) \cdot \mathrm{N}
$$

It follows from this last equation that global profits $(\pi)$ made from forced labourers are ultimately equal to the average number of units of goods or services produced by each worker (q) multiplied by the average price of these units (p), minus the sum of average wage (w) and intermediate consumption (c), and multiplied by the number of forced labourers $(\mathrm{N})$.

$$
\pi=[(\mathrm{q} \cdot \mathrm{p})-(\mathrm{w}+\mathrm{c})] . \mathrm{N}
$$

\footnotetext{
${ }^{14}$ This is a simplified expression of profits, which ignores rents and interest or capital depreciation.
} 
These equations show that the profits are not restricted to the earnings of networks who act only as intermediaries, recruiting and smuggling people across borders and "selling" them to criminal enterprises. The calculations refer to the broader annual profits made by the criminal agents or enterprises that exploit forced labourers at the point of destination (and out of which the intermediaries are being paid). That is, profits are the whole net value created by the work of forced labourers. ${ }^{15}$

\section{Forced economic exploitation}

The ILO data indicates that the majority of forced labourers work in traditional economic sectors, such as in agriculture, construction, domestic services and other labour-intensive sectors. According to the ILO estimate, there are about 8.1 million people in forced labour in these various sectors - a large majority of whom are located in Asia.

We have decided to estimate profits made from such forced labourers by using data on the value-added in agriculture. There are two reasons for this. First, many of the 8.1 million workers do work in agriculture. In Asia, in particular, a large share of the 6 million is made up by so-called bonded labourers in the traditional agriculture of South Asian countries. Thus, agriculture is most probably the single largest sector in which forced labour occurs. Second, the value-added in agriculture is also a good indicator of the average value-added in all the different low-skilled activities performed by forced labourers. In some sectors value-added may be lower, while in other sectors it may be higher. On average, however, we assume that these differences cancel each other out and that profits in agriculture are fairly representative for profits in all labour-intensive activities. This assumption is discussed in more detail below.

\subsection{Value-added and profits in agriculture}

As we have already said, agriculture is probably "host" to the largest number of forced labourers. While numbers in industrialized countries are a cause for concern, the problem of agricultural forced labour remains largest in developing countries. One particular problem is bonded labour in South Asia. Bonded labourers are people who lose their freedom of movement or their freedom of employment as a result of a debt and the obligation to reimburse this debt through labour. This, according to a Judgement by the Indian Supreme Court, amounts to forced labour because "any factor which deprives a person of a choice of alternative and compels him or her to adopt one particular course of action may be regarded as force, and if labour or services is compelled as a result of such force it would be forced labour". ${ }^{16}$ Most victims are sharecroppers ${ }^{17}$ who provide free labour to influential landlords as a means of paying off a debt that is often fraudulent, and sometimes inter-generational. In many instances, children of bonded parents are also made to work for the landlords in agricultural work or household chores and menial tasks. ${ }^{18}$

Agricultural forced labour also exists in Brazil and some other Latin American countries. Typically, workers are trafficked from poor places, where poverty and unemployment are high, to remote places in logging camps or in ranches. Once they reach their destination, workers find that they are trapped in debt bondage. They are usually told to work to repay a debt linked to the "cost" of transport and are also obliged to buy essentials, including food, from their employers at vastly inflated

\footnotetext{
${ }^{15}$ Whether this value accrues in cash or in kind is irrelevant. Some people may also argue that imposing forced labour on domestic workers does not generate profits (because unpaid domestic workers merely allow savings on household expenditure). We take a different view. Because domestic services create an economic value-added, we consider that these savings on expenditure count as profits.

${ }^{16}$ Indian Supreme Court Judgement dated 18.09.1982

${ }^{17}$ Sharecropping is a form of land tenancy under which workers surrender a portion (usually $50 \%$ ) of their produce to landlords in return for the use the land.

${ }^{18}$ To combat these practices, India and Pakistan have specific legislation against bonded labour.
} 
prices. In some regions of Latin America, ${ }^{19}$ indigenous people are also held captive through the open use of violence. The "enganche" or "habilitacion" labour systems, which are based on wage advances made to workers before the harvest in exchange for a commitment to work, are still used in some Andean countries. Often they result in debt bondage and forced labour. Bonded workers are usually males, but often workers' wives and children are also involved and expected to provide free labour.

In industrialized countries, most cases of forced labour involve migrant workers in the labourintensive segment of agriculture, where the share of labour costs in total production costs is highest and where labour costs are an important determinant of competitiveness. In the U.S., it is estimated that more than 1 million farm workers are employed every week. In the summer, this number climbs to more than 1.2 million (US Department of Agriculture, 2003). Most of these workers are low-educated migrant males in their 20s who are separated from their families and friends. It is estimated that half of them lack work authorization and plan to return to their home country in the off-season. They do not speak or read English well, and according to a survey (quoted in US Department of Agriculture, 1998) "most farm workers would have difficulty obtaining information from printed materials in any language". These workers are planting, cultivating, and harvesting crops or attending livestock throughout the country. The largest proportion works in the West in crop production such as fruit, vegetable, and horticultural crops. In the European Union, agriculture also relies heavily on migrant workers. According to the ICFTU (2003), about 4.5 million seasonal workers are employed every year on European fields and farms. Of these, an estimated 500,000 are from outside the 15 first member states - from North Africa and from Central or Eastern Europe.$^{20}$ According to a study commissioned by the European Federation of Food, Agriculture and Tourism Trade Unions (and quoted in ICFTU, 2003), these workers form part of a sector characterized by "insecurity and poverty wages", with salaries often below the legal minimum and inadequate health and safety conditions.

Of course, not all migrant workers in agriculture are in forced labour. Despite the poor conditions, there is no doubt that most migrants take up these jobs voluntarily - usually as a means to avoid poverty or unemployment in their countries of origin. However, the lack of legal protection and the geographical distance from their home makes migrant workers vulnerable to abusive practices. In the US, it is estimated that one farm worker out of five is not hired directly by farmers, but by farm labour contractors who "serve as intermediaries, often hiring, firing and supervising work in the workers' native language" (US Department of Labor, 2000). Similarly, in the EU countries many migrant agricultural workers are recruited through intermediaries, particularly in the UK and Italy. According to the ICFTU, these labour suppliers often take their commissions not from employers but out of the wages of the workers. In the UK, it is estimated that about $70 \%$ of seasonal workers are supplied by so-called "gang masters" who pay the workers directly, bill the farmers for their services, and make profits from deductions made from wages. In Italy, the role of the "gang master" is played by the "caporale". Intermediaries often make additional deductions from wages for transport costs, food, and administrative costs. In some instances - as in the Ramos case discussed in the introduction - the intermediaries use deception, violence, and forced labour. This is why one observer has called agriculture "ground zero for modern slavery". 21

How can we estimate the profits made from forced labour in agriculture? Equation [2] in section 2 of this paper indicated that profits are equal to workers' average economic value-added, minus the sum of expenditures on wage payments and on intermediate consumption. In the case of forced commercial sexual exploitation (discussed in the next section), no official data on economic valueadded is available and hence we will have to estimate it ourselves. In the case of agriculture, however, our task is easier, since the World Bank publishes every year in its World Development Indicators series a comprehensive data set on average economic value-added in agriculture. The data shown in the first column of table 3 represents agricultural value-added per worker in the year 2000-02, expressed in 1995 dollars. We see that value-added ranges from US\$ 30,154 per year (or about 2,500 per month) in industrial countries to US\$ 360 per year (or US\$ 30 per month) in Sub-Saharan Africa. In fact, we

\footnotetext{
${ }^{19}$ In particular in the Chaco region of Bolivia and Paraguay. See Bedoya and Bedoya Silva-Santisteban (2005 and 2005b)

${ }^{20}$ In Germany and Austria, most migrant workers are from Poland, Hungary or Romania. In Spain and Italy, they are mostly from Morocco. In Greece, they are from Albania, Bulgaria and Romania.

${ }^{21}$ John Bowe, Nobodies: Does slavery exist in America? The New Yorker, April 21 \& 28, 2003, pp. 107-108
} 
believe that these figures represent a fairly good approximation of the amount of annual profits made from agricultural forced labour at present. The next paragraph explains why.

Table 3: $\quad$ Annual value-added in agriculture

\begin{tabular}{|lcc|}
\hline & $\begin{array}{c}\text { Annual value added per person in } \\
\text { agriculture } \\
\text { in 2000- 2002 } \\
\text { (1995 constant US dollars) }\end{array}$ & $\begin{array}{c}\text { Estimated annual value-added } \\
\text { per person in agriculture } \\
\text { in 2005 } \\
\text { (2005 current dollars) }\end{array}$ \\
\hline Industrialized economies* & 30,154 & 37,242 \\
Transition economies & 2,353 & 2,906 \\
Asia \& Pacific & 412 & 509 \\
Latin America \& Caribbean & 3,570 & 4,409 \\
Sub-Saharan Africa & 360 & 445 \\
MENA & 2,340 & 2,890 \\
\hline
\end{tabular}

Source: based on World Bank, World Development Indicators, 2004 (p. 126);

* refers to High-Income Europe.

As we have already pointed out, the first column of table 3 represents the value-added in agriculture for the years 2000-02, expressed in constant 1995 US dollars (i.e. discounting for the increase in prices between 1995 and 2000-02). If we were to update this figure by adding an estimated 1.8 percent annual growth in agricultural value-added between 2001 and 2005 and by accounting for an estimated 15 percent increase in prices between 1995 and 2005, we would find an estimated valueadded for 2005 as shown in the second column of table 3 . We see that the figures would increase by about 25 percent. Assuming that the value-added of forced labourers is the same as the value-added of voluntary workers, we can interpret the second column of table 3 as the sum of profits and wage payments to forced labourers in agriculture.

To estimate the amount of profits, we need to deduct wage payments. As wage payments are usually below the market rate, we formulate the hypothesis that, on average, forced labourers are paid the equivalent of about 20 percent of their value-added. If we subtract these 20 percent from the second column of table 3 , we are back to the figures of the first column. Thus, we believe that agricultural value-added in 2000-02 at constant 1995 U.S. dollars is a good indicator of average profits from forced labour in agriculture in 2005.

How does our hypothesis of 20 percent wage payment for forced labourers compare to the wages of voluntary workers? Regarding industrial countries, our hypothesis implies that annual wage payments for forced labourers amount to approximately US $\$ 7,000$. What about voluntary workers? A recent National Agricultural Workers Survey has shown that hourly wages in agriculture are low, with a declining purchasing power, at just below US\$ 6 - with no benefits. ${ }^{22}$ Data from the US Department of Agriculture (2003) indicates that in 1997, full-time hired farm workers received median weekly earnings of US\$ 277, while data from the Bureau of Labor Statistics indicates that in 2003, nonunionized agricultural workers earned about US\$ 365 per week. ${ }^{23}$ Given the seasonality of farm employment, this translates into low annual wages. Although exact annual incomes cannot be computed, we estimate the median wage at somewhere between US\$10,000 and US\$15,000 per year. In Europe, based on ICFTU figures, we can calculate that the average hourly rate in the EU of an unskilled seasonal worker picking fruits or vegetables is similar, at about EURO 5.20 (see table 4). ${ }^{24}$ Thus, the average annual wage in low-skill agriculture probably lies at about US\$ 15'000. Overall, our assumption that 20 percent of value-added is used for wage payments therefore implies that wages for forced labourers amount to between one half and two thirds of the median wages of voluntary workers.

\footnotetext{
${ }^{22}$ US Department of Labour (2000)

${ }^{23} \mathrm{http}: / / \mathrm{www} . b l s . g o v /$ news.release/union2.t04.htm

${ }^{24}$ Figures reported in ICFTU (2003)
} 
Table 4: $\quad$ Unskilled agricultural wages in the EU (Euros)

\begin{tabular}{|lc|}
\hline Country & Hourly Rate \\
\hline Portugal & 2.30 \\
Greece & 3.50 \\
Spain & 4.60 \\
Germany & 5.40 \\
UK & 6.65 \\
France & 6.67 \\
Austria & 7.21 \\
\hline Average & 5.19 \\
\hline
\end{tabular}

Source : ICFTU (2003)

What about developing countries? In Asia we estimate average annual wages paid to forced labourers at about US\$ 100 . According to Indian statistics, ${ }^{25}$ for example, the all-India average daily wage rate in agricultural occupations in 2002-03 ranged from Rs. 30 for female herd-keepers to Rs. 83 for male labour engaged in well-digging. At current exchange rates, this represents roughly US\$ 0.7 to US\$ 2.0 per day, or probably between US\$ 200 and US\$ 600 per year. Thus, the estimated wage payment to forced labourers represents between one sixth and one half of average agricultural wages in India. This may seem low. But at the same time, converting US\$ 100 into purchasing power parity (PPP), we find that this represents about PPP US\$ 560. Thus, in our calculations, wage payments (in cash and/or in kind) to forced labourers amount to slightly more than the US\$ 1 dollar a day poverty line.

\subsection{Average value-added in low-skilled activities}

Forced labour occurs not only in agriculture, but also in other low skilled labour-intensive sectors such as the construction, garment, food processing and packaging industries, or domestic services. One example in the garment sector occurred a few years ago in a sweatshop in El Monte, California, where 72 workers from Thailand were held in servitude for up to seventeen years, sewing clothes in a compound enclosed by barbed wire and surrounded by armed guards. ${ }^{26}$ It is also worth pointing out that the largest trafficking case ever prosecuted in the U.S. (United States v. Kil Soo Lee) involved 200 Vietnamese and Chinese nationals, mostly young women, brought to American Samoa to work as sewing machine operators in a garment factory. These workers were held for up to two years and were forced to work through extreme food deprivation, beatings and physical restraints (U.S. Department of Justice, 2003). Domestic workers are also frequent victims. They are sometimes locked up, work extremely long hours, suffer from violence and other abuses and have their passports confiscated. In Europe, the U.S. and the Middle East, domestic workers in such conditions are mostly foreign migrants. In Latin America, Africa and Asia, they are often locals.

We believe that the value-added and the profits in all these activities are - on average - close to the value-added in agriculture. One way to see this is by looking at the level of market wages for voluntary workers in these activities. Similar wages can be interpreted as indicating similar value-added and similar profits per worker. Indeed, if one labour-intensive sector would yield substantially higher profits per worker than other similarly labour-intensive sectors, we would expect to see a massive reallocation of capital and labour towards that sector. Hence, at the market equilibrium, the value-added and profits per unskilled worker are likely to be similar in all low-skilled labour-intensive sectors.

Compared to the US\$ 365 per week in agriculture, the U.S. Bureau of Labor Statistics ${ }^{27}$ calculates that the median non-unionized worker earns US\$ 344 per week in food preparation and serving occupations, US\$ 372 in building and grounds cleaning and maintenance occupations, US\$ 490

\footnotetext{
${ }^{25}$ http://labourbureau.nic.in/wrr2sum.htm

${ }^{26}$ see http://www.sweatshopwatch.org/swatch/campaigns/elmonte.html

${ }^{27} \mathrm{http}: / /$ www.bls.gov/news.release/union2.t04.htm
} 
in transportation and material moving occupation, and US\$ 530 in construction and extraction occupations. Hence, the average annual wage of voluntary low-skilled workers in these occupations is likely to be similar to or slightly above wages in agriculture. On the other hand, wages and productivity of domestic workers are likely to be somewhat lower than in agriculture. The U.S. Department of Agriculture (1998) reported for example that household workers were paid 25 percent less than fulltime hired farm workers. Our hypothesis is that, on average, differences in wages, productivity and profits cancel each other out. Therefore, we believe that average profits in agriculture are a fairly good indicator of average profits in all low-skilled activities.

\subsection{Estimating the profits from forced economic exploitation}

To estimate the total profits from forced economic exploitation, we multiply the number of victims by their estimated average profits. As indicated above, average profits are estimated through data on value-added in agriculture. This data shows that profits range from US\$ 30 '000 in industrialized economies to less than US\$ 400 in Sub-Saharan Africa. Unfortunately, there are not many case studies on the profits of forced economic exploitation against which to assess these estimates. According to one report by O'Neill Richards (1999), the Thai traffickers who incarcerated Thai women and men in a sweatshop in El Monte, California (US), were estimated to have made US\$ 8 million over six years. Sixty-four workers who were freed by a police raid in 1995 filed a suit. ${ }^{28}$ Some of these workers had been locked up for seven years, others for shorter periods. Assuming that workers were held captive for an average of 4 years, annual profits would represent US\$32'000 per worker - virtually identical to our estimate for industrial countries.

In the tables below, two different calculations are made: one for all forced labourers and another one for trafficked forced labourers only.

Profits from all forced economic exploitation: we find that the total illegal profits made with the world's 8.1 million forced labourers in economic exploitation reach US\$ $\mathbf{1 0 . 4}$ billion. The profits are highest in industrial countries and Latin America (about US\$ 3.5 billion each). In Asia, profits are slightly lower (US\$ 2.5 billion) despite the high number of victims. This reflects the fact that most people in forced labour are workers with a very low average value-added.

Profits from trafficked people in forced economic exploitation: when restricting our calculations to the world's 1.1 million victims of human trafficking for forced economic exploitation, we find that total profits amount to US\$ 3.8 billion. The profits are by far highest in industrial countries (US\$ 2.2 billion). In the other regions, profits vary between US\$ 40 million in Sub-Saharan Africa and US\$ 776 million in Latin America.

Table 5: $\quad$ Estimated annual profits from all forced economic exploitation

\begin{tabular}{|lccc|}
\hline & $\begin{array}{c}\text { Value-added per worker } \\
\text { (US\$) }\end{array}$ & $\begin{array}{c}\text { Number of people in } \\
\text { forced labour }\end{array}$ & $\begin{array}{c}\text { Total profits } \\
\text { (US\$'000) }\end{array}$ \\
\hline Industrialized Economies & 30,154 & 113,000 & $3,407,000$ \\
Transition Economies & 2,353 & 61,500 & 145,000 \\
Asia \& Pacific & 412 & $6,181,000$ & $2,547,000$ \\
L.America \& Caribbean & 3,570 & 995,500 & $3,554,000$ \\
Sub-Saharan Africa & 360 & 537,500 & 194,000 \\
MENA & 2,340 & 229,000 & 536,000 \\
\hline World & & & $10,382,000$ \\
\hline
\end{tabular}

\footnotetext{
${ }^{28}$ see, for example, sweatshopwatch.org
} 
Table 6: $\quad$ Estimated annual profits from trafficked people in forced economic exploitation

\begin{tabular}{|lccc|}
\hline & $\begin{array}{c}\text { Value-added per worker } \\
\text { (US\$) }\end{array}$ & $\begin{array}{c}\text { Number of trafficked } \\
\text { people in forced labour }\end{array}$ & $\begin{array}{c}\text { Total profits } \\
\text { (US\$'000) }\end{array}$ \\
\hline Industrialized Economies & 30,154 & 74,133 & $2,235,000$ \\
Transition Economies & 2,353 & 59,096 & 139,000 \\
Asia \& Pacific & 412 & 408,969 & 168,000 \\
L.America \& Caribbean & 3,570 & 217,470 & 776,000 \\
Sub-Saharan Africa & 360 & 112,444 & 40,000 \\
MENA & 2,340 & 203,029 & 475,000 \\
& & & $3,834,000$ \\
\hline World & $1,075,140$ & \\
\hline
\end{tabular}

\section{Forced commercial sexual exploitation (CSE)}

What are the profits in forced commercial sexual exploitation? As we have seen above, the ILO has estimated that there are about 1.7 million victims of such practices - most as a result of human trafficking. These include mostly women and children forced into prostitution. ${ }^{29}$ Data collected by the Dutch National Rapporteur on Trafficking in Human Beings. ${ }^{30}$ (2003) show that forced prostitution usually occurs in clubs and brothels (and also "window prostitution"), rather than in escort agencies or in street prostitution.

\subsection{The victims}

In industrial countries, the victims are overwhelmingly foreign women who have been trafficked. ${ }^{31}$ While some are sold by their parents or kidnapped, the data shows that most victims are recruited by traffickers under false pretences. Traffickers often approach women in their countries of origin, promising jobs as waitresses, cleaners or maids. Other women know that they are recruited to work in the sex industry but only find out upon arrival that they are forced to work off fraudulent debts. Some women even find out that they have several "debts" - fees of travel agents, smugglers, labour contractors and so on. As in the case of Marika described in the introduction, victims are usually told that they will be free only once they have paid off this "debt", which typically varies between US\$ 3,000 and US\$ 60,000 . Some trafficked women are held in confinement, but most are maintained in prostitution through threats, beatings, and/or the retention of identity documents. Traffickers include international crime syndicates but also private individuals - often people with the same nationality as the victims, sometimes even family members. The health consequences are devastating. Many victims contract AIDS or sexually transmitted diseases. Forced abortions and psychological trauma are also widespread.

Forced prostitution also exists in transition and developing countries. The modalities are similar to those in industrialized countries. There are some distinctions, however. First, more cases relate to intra-regional trafficking than to inter-regional trafficking. This means that victims in Latin America, Asia or Sub-Saharan Africa are usually from within these same regions. Often they are trafficked internally (i.e. within the same country). Second, forced child prostitution is more frequently reported in developing countries than in industrial countries. This problem is often linked to child sex tourism,

\footnotetext{
${ }^{29}$ Prostitution is defined by Edlund and Korn as "the act of rendering, from the client's point of view, non-reproductive sex against payment" (2002, p.183)

${ }^{30}$ An independent institution whose main task is to collect data and report to the Dutch authorities

${ }^{31}$ In Europe, most cases involve Eastern European and African victims, while in the U.S. they involve victims from Latin America and Asia. In Australia and Japan, a majority of victims are reported to be of Thai and other Asian origin.
} 
which involves persons who travel to a foreign country to engage in commercial sex with children especially in some Southeast Asian countries. Forced sexual exploitation can also be linked to religious beliefs. This is, for example, the case of the "Devadasi" in India, forced into prostitution in the name of a goddess, or the "Trokosi" in Ghana who are enslaved to fetish priests.

\subsection{Estimating the profits in forced CSE}

Unsurprisingly, there is little official data on the economics of prostitution. In fact, the very notion of economic "value-added" may seem inappropriate when applied to prostitution and is sometimes rejected by anti-prostitution groups. However, prostitution is usually considered as a productive economic activity - independently of any moral consideration. According to the definitions provided in the System of National Accounts (SNA) $1993,{ }^{32}$ prostitution falls within the scope of the production boundary and hence should be included in the calculation of a country's GDP. ${ }^{33}$ The legality or illegality of prostitution is irrelevant, as both legal and illegal production should be included in the systems of national accounts. ${ }^{34}$ By excluding illegal or underground activities, national accounts would simply exclude monetary transactions that actually take place and hence would provide a distorted picture of reality. It should be clear that by referring to the activity and to the revenue it generates, the ILO does not endorse or legitimise it.

The lack of data on the economic value-added of prostitution is largely explained by the fact that prostitution is usually part of the non-observed economy (NOE). Indeed, in most cases, brothels are not registered and, when they are registered, they are often registered under incorrect activity descriptions such as massage shops or nightclubs. The recent increase in migrant women in prostitution has made this activity even more unobservable. In Europe, the share of foreign prostitutes now probably exceeds 50 percent. One document published by the French Parliament estimates, for example, that more than $60 \%$ of prostitutes in Paris are foreigners. ${ }^{35}$ According to some reports, the internationalization of prostitution has been accompanied by a growing involvement of criminal networks and of mafia-type organizations, which also trade arms and drugs. This, of course, makes data collection even more difficult.

In the absence of official data, we have no other choice but to use rough estimates. As we have indicated in section 2, total profits in forced commercial sexual exploitation can be calculated by estimating the average profits (value-added) per victim and multiplying it by the total number of victims. Following OECD et al (2002), this kind of method gives a first approximation of the total value of economic transactions. To estimate average profits per victim, we need information on average prices paid by clients, the number of clients, and the expenditures for wage payments and intermediate consumption.

- Prices: The price of sexual services is determined by a number of factors, including the level of income of the country where the transaction takes place and the legal regime of that country. Typically, the price of sexual services will be higher in rich countries with a prohibitive legal regime (where there is a risk premium included in the price) and lowest in poor countries with few restrictions. We have estimated average prices per region. Based on a large quantity of information collected in various sources including a tourist guide focusing on the sex sector, we estimate that average prices range from US\$ 15-16 in Asia and Sub-Saharan Africa to US\$ 100 in industrial countries. Results are shown in the first column of table 7.

- Number of clients: Regarding the number of transactions, we estimate that each prostitute has an average of about 80 clients per month - an assumption based on information collected from a

\footnotetext{
${ }^{32}$ Commission of the European Communities et al. Systems of National Accounts 1993 quoted in OECD et al., 2002.

${ }^{33}$ Like other economic production, prostitution meets the criteria of activities "carried out under the control and responsibility of an institutional unit that uses inputs of labour, capital, and goods and services to produce outputs of goods or services...of a kind that can be delivered or provided to other institutional units" (1993 SNA: 6.15 and 6.6). Institutional units refer to persons, groups of persons or legal or social entities.

${ }^{34}$ OECD, 2002, p.38

${ }^{35}$ Assemblée Nationale (2001)
} 
number of sources of information on prostitution in general. We believe that this is a conservative estimate. Forced commercial sexual exploitation is by definition a business of coercion. To maximize profits, brothel owners often force victims to have as many customers as possible per day, and based on a review of the ILO's database used for the global estimate, it seems that 5 to 10 customers per day is relatively normal for a victim (whereas our estimate is based on 3 to 4 customers per day).

- Wages and intermediate consumption: Payments to victims are often very low - which is precisely what makes forced commercial sexual exploitation so lucrative. According to Essy van Dijk (2002) of the Bureau of the Dutch National Rapporteur on Trafficking of Human Beings, for example, most of the trafficking victims in the Netherlands receive no payment at all. Laczko and Gramegna (2003), who have studied an IOM database with 826 victims of trafficking mostly for sexual exploitation, confirm that over half of the victims reported that they received no income for providing sexual services, and most of the others reported receiving some money from time to time. Based on such evidence as well as on one recent Interpol report, ${ }^{36}$ which describes the accounts of pimps in Finland, we estimate the sum of wage payments and intermediate consumption at 30 percent of total turnover.

With this information, we can now calculate average profits per victim. In table 7 , the second column shows average turnover per victim. It is obtained by multiplying the average prices by the average number of clients. The third column shows our estimate of the average profit per victims. It is calculated as 70 percent of total turnover.

Table 7: $\quad$ Estimated annual profits per victim of forced commercial sexual exploitation

\begin{tabular}{|lccc|}
\hline & $\begin{array}{c}\text { Average Prices of } \\
\text { sexual services (US\$) }\end{array}$ & $\begin{array}{c}\text { Turnover per victim per } \\
\text { year (US\$) }\end{array}$ & $\begin{array}{c}\text { Annual profits per } \\
\text { victim (US\$) }\end{array}$ \\
\hline Industrialized Economies & $\mathbf{p})$ & $\mathbf{( p . q )}$ & {$[(\mathbf{p} \cdot \mathbf{q})-(\mathbf{w}+\mathbf{c})]$} \\
\hline Transition Economies & 100 & 96,000 & 67,200 \\
Asia \& Pacific & 35 & 33,600 & 23,500 \\
Latin America \& Caribbean & 15 & 14,400 & 10,000 \\
Sub-Saharan Africa & 27 & 25,920 & 18,200 \\
MENA & 16 & 15,360 & 10,000 \\
\hline
\end{tabular}

In the next two tables, we calculate total profits from forced commercial sexual exploitation by multiplying average profits per victim by the estimated number of victims. We do this calculation for all victims of forced commercial sexual exploitation, as well as for only those victims who have been trafficked. The results certainly confirm the assessment of a recent report by Free the Slaves and the Human Rights Center of the University of California (2004) that the trafficking of women for prostitution is a highly profitable activity.

Profits from all forced commercial sexual exploitation: In table 8 we calculate profits made from all victims of forced commercial sexual exploitation. We find that profits in the world amount to US\$ 33.9 billion, with almost half - US\$ 15.4 billion - realized in industrial countries. Asia is the region with the second highest profits (US\$ 11.2 billion), followed by transition countries (US\$ 3.5 billion), Latin America (US\$ 2.1 billion), and Middle-East and North Africa (US\$ 1.1 billion). Sub-Saharan Africa is the region where these criminal profits are lowest (US $\$ 0.5$ billion).

\footnotetext{
${ }^{36}$ Interpol, Finland Report 2002
} 
Table 8: $\quad$ Estimated annual profits from forced commercial sexual exploitation (CSE)

\begin{tabular}{|lccc|}
\hline & $\begin{array}{c}\text { Annual profits per } \\
\text { prostitute (US\$) }\end{array}$ & $\begin{array}{c}\text { Number of people in } \\
\text { forced prostitution }\end{array}$ & $\begin{array}{c}\text { Total annual profits } \\
\text { (US\$'000) }\end{array}$ \\
\hline Industrialized Economies & 67,200 & 229,000 & $15,388,800$ \\
Transition Economies & 23,500 & 149,500 & $3,513,250$ \\
Asia \& Pacific & 10,000 & $1,119,000$ & $11,190,000$ \\
Latin America \& Caribbean & 18,200 & 116,500 & $2,120,300$ \\
Sub-Saharan Africa & 10,000 & 56,500 & 565,000 \\
MENA & 45,000 & 25,000 & $1,125,000$ \\
\hline World & & & $33,902,350$ \\
\hline
\end{tabular}

Profits from forced commercial sexual exploitation as a result of trafficking: In table 9 we replicate the same calculations but restricted to the ILO's estimated number of people who are in forced commercial sexual exploitation as a result of human trafficking. ${ }^{37} \mathrm{We}$ find that the global profits made from trafficking into forced commercial sexual amount to US\$ 27.8 billion, with similar regional distribution. Almost half of all profits - US\$ 13.3 billion - are made with people trafficked into or within industrial countries. Second highest profits are in Asia (US\$ 9.5 billion), followed by transition economies (US\$ 3.2 billion), Middle-East and North Africa (US\$ 1.0 billion), Latin America (US\$ 0.6 billion) and Sub-Saharan Africa (US\$ 0.1 billion).

Table 9: $\quad$ Estimated annual profits from forced CSE with trafficked victims

\begin{tabular}{|lccc|}
\hline & $\begin{array}{c}\text { Annual profits per } \\
\text { prostitute (US\$) }\end{array}$ & $\begin{array}{c}\text { Number of trafficked people } \\
\text { in forced commercial sexual } \\
\text { exploitation }\end{array}$ & $\begin{array}{c}\text { Total annual profits } \\
\text { (US\$'000) }\end{array}$ \\
\hline Industrialized Economies & 67,200 & 197,585 & $13,277,712$ \\
Transition Economies & 23,500 & 139,697 & $3,282,867$ \\
Asia \& Pacific & 10,000 & 953,598 & $9,535,980$ \\
Latin America \& Caribbean & 18,200 & 31,420 & 571,844 \\
Sub-Saharan Africa & 10,000 & 11,835 & 118,345 \\
MENA & 45,000 & 22,948 & $1,032,660$ \\
\hline World & & $1,357,082$ & $\mathbf{2 7 , 8 1 9 , 4 0 8}$ \\
\hline
\end{tabular}

\subsection{Assessing the results}

To assess our estimates and determine whether they are reasonable, we review a number of case studies. We focus, in particular, on the two main regions - industrial countries and Asia - which together account for around 80 percent of global profits. Overall, we believe this review of case studies supports our estimates as plausible figures.

In industrial countries, we have estimated the average annual turnover of forced commercial sexual exploitation at almost US\$100,000 per year per victim, with profits at US\$ 67,200 per year (or US\$ 5,600 per month). What about the evidence from available case studies?

\footnotetext{
${ }^{37}$ The numbers also differ slightly from those of the ILO because they include 50 percent of those classified by the ILO in "undetermined" forms of forced labour.
} 
- One recent report by Interpol (2002) describes a case in Finland where the police seized accounts from pimps, showing that 5 to 8 voluntary prostitutes provided sexual services worth EURO 50,000 per month. This represents a turnover of between EURO 75'000 and EURO 120,000 per year per woman - in line with our estimate of US\$100,000.

- In one recently prosecuted case in the U.K. (the so-called "Plakici case"), the traffickers apparently earned an income of $£ 144,000$ - i.e. about US\$276,000 - by forcing a 16 year-old girl into prostitution during two years. This represents about US\$ 140,000 per year - again exceeding our estimate. ${ }^{38}$

- A 1998 investigation by the Canadian Police ${ }^{39}$ into a prostitution network revealed that brothel keepers made about US\$ 5 million annual profits with 100 trafficked women. This amounts to annual profits of US\$ 50,000 per women - slightly lower than our number.

In Asia, we have estimated turnover per prostitute at about US\$ 15,000 and profits at US\$ 10,000 per year (or US\$ 833 per month).

- Kevin Bales (1999) calculated that in Thailand a girl in a brothel has 14 clients a day for 30 days, with a cost of US\$ 5 per client. This implies a turnover of US\$2,100 per month or US\$ 25,200 per year. Allowing for rent and other intermediate consumption, this leaves a value-added of about US\$18,000 per year - more than our figure of US\$10,000.

- Information from an ILO publication indicates that the turnover by middle-range prostitutes reaches about US\$ 14,400 per year in Indonesia and US\$ 33,600 in Malaysia - compared to our estimated average of US\$15,000.

- One recent newspaper article ${ }^{40}$ indicated that in Bombay (India), prostitutes charge customers from US\$ 4 up to US\$ 10 and that they have about 6 customers per day. Thus, if prostitutes are being forced to work seven days a week all year round, they can generate a turnover of between US\$ 8,600 and US\$21,600 with an average of US\$ 15,000 - which corresponds to our regional estimate.

- Finally, one article ${ }^{41}$ indicates that voluntary prostitutes in China earn about Yuan 25,000 per year or US\$3,000. Assuming that these earnings represent half of the total value of services, we can estimate total turnover to be US\$ 6,000 year - lower than our figure.

\section{All Forms of Forced Labour}

The ILO (2005) found that there are at least 12.3 million people in forced labour worldwide. Out of these, 9.8 million are exploited by private agents and enterprises - approximately 2.5 million of whom are victims of trafficking. As we have discussed above, victims of forced labour and trafficking are used either for commercial sexual exploitation or for economic exploitation. We have estimated profits in both types of exploitation. We can now bring together our estimates to calculate the total profits made from forced labour and human trafficking.

Profits from all forced labour: We estimate that the global profits made by private agents and enterprises with the world's 9.8 million forced labourers amount to US\$ $\mathbf{4 4 . 3}$ billion per year. This represents roughly US\$ 4,500 per victim per year. The largest profits are made in industrial countries (US\$ 18.8 billion), followed by Asia (US\$13.7 billion), Latin America (US\$ 5.7 billion) and transition

\footnotetext{
${ }^{38} \mathrm{http} / / \mathrm{www}$.dailyrecord.co.uk/printable version.cfm?objectid $=13750875 \&$ siteid $=89488$

$39 \mathrm{http} / / /$ www.protectionproject.org/human_rights/countryreport/canada.htm

${ }^{40}$ Sabin Russel, "The Role of Prostitution in South Asia's Epidemics: Push for Safe Sex in Red-Light Districts", San Francisco Chronicle, July 5, 2004

${ }^{41}$ Zhong Wei, “A Close Look at China's Sex Industry”, http://www.usembassy-china.org.cn/sandt/sex-industry.html
} 
countries (US\$ 3.6 billion). The two regions where profits are lowest are the Middle East and North Africa (US\$ 1.6 billion) and Sub-Saharan Africa (US\$ 0.7 billion).

Profits from all trafficked forced labourers: We estimate that the global profits made with the world's 2.5 million forced labourers who have been trafficked amount to US\$ 31.6 billion per year. This represents an annual average of US\$ $13^{\prime} 000$ per victim. Thus, profits are higher with trafficked victims than with non-trafficked victims. Profits are by far the highest in industrial countries (US\$ 15.5 billion), followed by Asia (US\$ 9.7 billion), transition countries (US\$ 3.4 billion) and Middle East and North Africa (US 1.5 billion). The two regions where profits are lowest are Latin America (US\$ 1.3 billion) and Sub-Saharan Africa (US\$ 0.1 billion).

Table 10: Annual profits from all forced labour

\begin{tabular}{|l|ccc|}
\hline & $\begin{array}{c}\text { Total profits in forced } \\
\text { commercial sexual } \\
\text { exploitation } \\
\text { (US\$ million) }\end{array}$ & $\begin{array}{c}\text { Total profits in } \\
\text { economic exploitation }\end{array}$ & Global Profits \\
(US\$ million) & (US\$ million) \\
\hline Industrialized Economies & 15,388 & 3,407 & 18,796 \\
Transition Economies & 3,513 & 145 & 3,658 \\
Asia and the Pacific & 11,190 & 2,547 & 13,736 \\
Latin America \& Caribbean & 2,120 & 3,554 & 5,674 \\
Sub-Saharan Africa & 565 & 194 & 758 \\
MENA & 1,125 & 536 & 1,661 \\
\hline World & & & $\mathbf{4 4 , 2 8 4}$ \\
\hline
\end{tabular}

Table 11: Annual profits from all trafficked forced labourers

\begin{tabular}{|lccc|}
\hline & $\begin{array}{c}\text { Total profits in forced } \\
\text { commercial sexual } \\
\text { exploitation } \\
\text { (US\$ million }\end{array}$ & $\begin{array}{c}\text { Total profits in economic } \\
\text { exploitation }\end{array}$ & Global Profits \\
(US\$ million) & (US\$ million) \\
\hline Industrialized Economies & 13,277 & 2,235 & 15,513 \\
Transition Economies & 3,283 & 139 & 3,422 \\
Asia and the Pacific & 9,536 & 168 & 9,705 \\
Latin America \& Caribbean & 572 & 776 & 1,348 \\
Sub-Saharan Africa & 118 & 40 & 158 \\
MENA & 1,033 & 475 & 1,508 \\
\hline World & 27,820 & 3,834 & 31,654 \\
\hline
\end{tabular}

\section{Conclusion}

The main finding of this paper is that the profits of forced labour could amount to US\$ 44.3 billion per year, of which US\$ 31.6 billion are made by exploiting trafficked victims. This confirms that "modern slavery" is a lucrative business, which funds the expansion of international criminal groups, contributes to corruption, and undermines the rule of law.

To some readers the figures calculated in this paper may seem surprisingly high. Previous estimates of the "profits of trafficking" have been lower, ranging typically from US\$ 3 billion to US\$ 10 billion (Schloenhardt, 1999). One figure which is often quoted estimates at US\$ 5-7 billion the annual profits for gangster syndicates who traffic people (Widgren, 1994). More recently, the U.S. intelligence community has estimated that human trafficking generates US\$ 9.5 billion in annual 
revenues (U.S. Department of State, 2004). UNICEF (2003) also reports that the trafficking in persons generates US\$ 7 billion to US\$ 10 billion annually for traffickers. In most of these studies, however, it is unclear how profits were calculated. In some other studies, calculations actually refer to what would now be called the profits of human smuggling instead of the profits of trafficking. For example, Widgren's figure of US\$ 5-7 billion annual income from "trafficking" refers in fact to the profits of "gangster syndicates" that smuggle people across borders illegally. This is very different from the kind of profits we have calculated.

It is also worth emphasizing that there are several groups of people who benefit from trafficking: the recruiter, the transporter/smuggler, and the final exploiter. Andrees (2004) points out that these groups are not always "part of an organized crime network: the smuggler can be an individual (i.e. a taxi driver) transporting irregular migrants for a fee across the border; the recruiter can be a perfectly legal recruitment agency and the same can be said for the employer". It is possible that some of the earlier profits calculations have focused only on profits made by one or other of these groups, in particular the transporter/smuggler.

Despite the large numbers, we believe that our estimates are conservative. Our figure of US\$ 44 billion implies annual profits of about US\$ 4,500 for each forced labourer. This is equal to less than US\$ 400 per month per victim and can hardly be a huge overestimate (even allowing for the fact that many victims are poor agricultural workers). Our estimate of US\$32 billion for trafficking implies higher annual profit of US\$13,000 per victim. But here again this represents little more than US\$1,000 per month - a figure that does not seem excessive given the high share of trafficking for forced prostitution and the high profits that can be made in the sex industry.

Of course, we can never emphasize enough that the new figures calculated in this paper are only tentative estimates and that much more work is needed to understand fully the economics of forced labour. These new figures nevertheless suggest that some of the previous estimates could be significantly underestimating real profits. But much more research is needed to establish a precise picture of the economics of forced labour and human trafficking. Future research may focus on better data collection, the analysis of case studies, and also on the economic dimensions of State-imposed forced labour. 


\section{Bibliography}

Andrees, Beate. 2004. "ILO Research on the forced labour outcomes of human trafficking and irregular migration”, paper for the IOM International Expert Meeting, Rome, May, (draft).

Assemblée Nationale. 2001. L'esclavage, en France, aujourdh'hui, Les documents d'information de l'assemblée nationale, Paris.

Bales, Kevin. 1999. Disposable People. University of California Press, USA.

Bedoya Eduardo, and Alvaro Bedoya Silva-Santisteban. 2005. El Trabajo Forzoso en la Extraccion de la Madera en la Amazonia Peruana, DECLARATION Working Paper 40, ILO, Geneva.

Bedoya Eduardo, and Alvaro Bedoya Silva-Santisteban. 2005a. Enganche y Servidumbre por Deudas en Bolivia, DECLARATION Working Paper, ILO, Geneva.

Belser, Patrick, Michaelle de Cock, and Farhad Mehran. 2005. An ILO Minimum Estimate of Forced Labour in the World, International Labour Office, Geneva.

Berger, John. 1985. The Sense of Sight. Vintage International, New York, USA.

Comité contre l'Esclavage Moderne. 2004. Statistiques (1998-mars 2003).

Corradini, Louise. 2001. "Ninos Encadenados", UNESCO,

http://www.unesco.org/courier/2001 06/sp/droits.htm

Dutch National Rapporteur on Trafficking in Human Beings. 2003. Trafficking in human beings; supplementary figures, Bureau NRM, The Hague.

Edlund, Lena and Evelyn Korn. 2002. “A Theory of Prostitution”, Journal of Political Economy, Vol. 110, no.1, pp-181-214.

Free the Slaves \& Human Rights Center University of California. 2004. Hidden Slaves: Forced Labour in the United States.

Galiana, Carmen. 2000. “Trafficking in Women”, European Parliament, Working Paper, Civil Liberty Series LIBE 109 EN.

Fukuda-Parr, Sakiko. 2003. "New Threats to Human Security in the Era of Globalization", Journal of Human Development, Vol.4, No.2, July.

Laczko, Frank and Marco Gramegna. (2003). "Developing Better Indicators of Human Trafficking", Brown Journal of World Affairs, Summer/Fall, Vol.X, Issue 1.

Malarek, Victor. 2003. The Natashas: The new Global Sex Trade, Viking Canada, Toronto

United Nations. 2000. Protocol to Prevent, Suppress, and Punish Trafficking in Persons, Especially Women and Children, Supplementing the United Nations Convention Against Transnational Organized Crime, New York.

ICFTU. 2003. "Migrants in European Agriculture: Open Season from Exploitation", Trade Union World Briefing, December, No.7

ILO. 2005. A Global Alliance Against Forced Labour, Global Report under the Follow-up to the ILO Declaration on Fundamental Principles and Rights at Work, Geneva. 
ILO. 2001. Stopping Forced Labour, Global Report under the Follow-up to the ILO Declaration on Fundamental Principles and Rights at Work, Geneva.

Interpol. 2002. Finland Report 2002, National Situation Report.

http://www.interpol.int/Public/THB/Women/situationReports/2002/finland.asp

OECD, IMF, ILO and CIS STAT. 2002. Measuring the Non-Observed Economy: A Handbook, OECD, Paris.

O’Neill Richards, Amy. 1999. "International Trafficking in Women to the United States: A Contemporary Manifestation of Slavery and Organized Crime", DCI Exceptional Intelligence Analyst Program, An Intelligence Monograph, Center for the Study of Intelligence, November.

Schloenhardt, Andreas. 1999. "Organised Crime and the Business of Migrant Trafficking: An economic analysis", Australian Institute of Criminology, AIC Occasional Seminar, Canberra, November.

UNICEF. 2003. End Child Exploitation : Stop the traffic, UNICEF, UK.

UNIDO (United Nations Industrial Development Organization). 2001. International Yearbook of Industrial Statistics.

U.S. Department of Justice. 2003. "Assessment of U.S. Activities to Combat Trafficking in Persons", Washington D.C, August.

U.S. Department of State. 2003. Trafficking in Persons Report, Washington D.C.

U.S. Department of Agriculture. 2003. "Farm Labor", National Agricultural Statistical Services (NASS), Washington D.C, August 15.

U.S. Department of Agriculture. 1998. "Hired Farm Labour in U.S. Agriculture", Agricultural Outlook/October, Economic Research Service.

US Department of Labor. 2000. "Findings from the National Agricultural Workers Survey (NAWS) 1997-98", Office of the Assistant Secretary for Policy, Office of Program Economics, Research Report No. 8, Washington D.C, March.

Van Dijk, Essy. (2002). Mensenhandel in Netherland 1997-2000, Zotermeer, KLPD/NRI.

Jonas Widgren. 1994. "Multilateral Co-operation to Combat Trafficking in Migrants and the Role of International organizations", Discussion Paper for the Eleventh IOM Seminar. October. Geneva.

World Bank. 2004. 2004 World Development Indicators, Washington, D.C. 
List of Working Papers of the InFocus Programme on Promoting the Declaration

No. 1 Bonded Labour in Pakistan, by Aly Ercelawn and Muhammad Nauman, June 2001.

No. 2 A Perspective Plan to Eliminate Forced Labour in India, by L. Mishra, July 2001.

No. 3 Défis et opportunités pour la Déclaration au Bénin, by Bertin C. Amoussou, August 2001.

No. 4 Défis et opportunités pour la Déclaration au Niger: Identification des obstacles à la mise en œuvre des principes et droits fondamentaux au travail et propositions et solutions au Niger, by Moussa Oumanou, August 2001.

No. 5 Égalité de rémunération au Mali, by Dominique Meurs, August 2001.

No. 6 Défis et opportunités pour la Déclaration au Burkina Faso, by Seydou Konate, September 2001.

No. 7 Child Labour in the Russian Federation, by Svetlana Stephenson, June 2002.

No. 8 Intersecting risks: HIV/AIDS and Child Labour, by Bill Rau, June 2002.

No. 9 Los principios y derechos fundamentales en el trabajo: su valor, su viabilidad, su incidencia y su importancia como elementos de progreso económico y de justicia social, de María Luz Vega Ruiz y Daniel Martínez, Julio 2002.

No. 10 The Links between Collective Bargaining and Equality, by Adelle Blackett and Colleen Sheppard, September 2002.

No. 11 Annotated bibliography on forced/bonded labour in India, by Mr. L. Mishra, December 2002.

No 12 Minimum wages and pay equity in Latin America, by Damian Grimshaw and Marcela Miozzo, March 2003

No. 13 Gaps in basic workers' rights: Measuring international adherence to and implementation of the Organization's values with public ILO data, by W. R. Böhning, May 2003.

No. 14 Equal Opportunities Practices and Enterprises Performance: An investigation on Australian and British Data, by Prof. V. Pérotin, Dr. A. Robinson and Dr. J. Loundes, July 2003

No. 15 Freedom of Association and Collective Bargaining, a study of Indonesian experience 19982003, by Patrick Quinn, September 2003

No. 16 Gender-based occupational segregation in the 1990s, by Richard Anker, Helinä Melkas and Ailsa Korten, September 2003.

No. 17 Normalised and Disaggregated Gaps in Basic Workers' Rights, by W.R. Böhning, November 2003

No. 18 Forced Labour: Definition, Indicators and Measurement, by Kanchana Ruwanpura \& Pallavi Rai, March 2004.

No. 19 Pay equity, minimum wage and equality at work: theoretical framework and empirical evidence, by Jill Rubery, November 2003 
No. 20 A rapid assessment of bonded labour in Pakistan's mining sector, by Ahmad Salim, March 2004.

No. 21 A rapid assessment of bonded labour in hazardous industries in Pakistan: glass bangles, tanneries and construction, by the Collective for Social Science Research in Karachi, March 2004.

No. 22 A rapid assessment of bonded labour in domestic work and begging in Pakistan, by the Collective for Social Science Research in Karachi, March 2004.

No. 23 A rapid assessment of bonded labour in the carpet industry of Pakistan, by Zafar Mueen Nasir, March 2004.

No. 24 Unfree labour in Pakistan - work, debt and bondage in brick kilns in Pakistan, by the Pakistan Institute of Labour Education \& Research, March 2004.

No. 25 Bonded labour in agriculture: a rapid assessment in Punjab and North West Frontier Province, Pakistan, by G.M. Arif, March 2004.

No. 26 Bonded labour in agriculture: a rapid assessment in Sindh and Balochistan, Pakistan, by Maliha H. Hussein, Abdul Razzaq Saleemi, Saira Malik and Shazreh Hussain, March 2004.

No. 27 Las desigualdades étnicas y de género en el mercado de trabajo de Guatemala, de Pablo Sauma, Marzo 2004.

No. 28 Libertad de asociación, libertad sindical y el reconocimiento efectivo del derecho de negociación colectiva en América Latina: el desarollo práctico de un principio fundamental, de Maria Luz Vega-Ruiz, Abril 2004.

No. 29 Etude sur le travail forcé en Afrique de l'Ouest : le cas du Niger, de Ali R. Sékou et Souley Adji.

No. 31 Human trafficking in Europe: an Economic Perspective, by Gijsbert Van Liemt, June 2004.

No. 32 Chinese migrants and forced labour in Europe, by Gao Yun, August 2004 (English, French $\&$ Chinese version)

No. 33 Trafficking of migrant workers from Romania: issues of labour and sexual exploitation, by Catalin Ghinararu \& Mariska N.J. van der Linden, September 2004.

No. 34 Recruitment for employment abroad: law, policies and current practice in Romania, by Catalin Ghinararu, March 2005.

No. 35 Methodology for estimating labour costs by sex, by Laís Abramo, Silvia Berger, Héctor Szretter and Rosalba Todaro, September 2004.

No. 36 The labour dimensions of irregular migration and human trafficking in Turkey, by Prof. Ahmet İçduygu \& Şhebnem Koşar Akçapar, March 2005.

No. 37 Trafficking of migrant workers from Albania: issues of labour \& sexual exploitation, by ICMC Center for Refugee and Migration Studies (CRMS), March 2005.

No. 38 Forced labour outcomes of migration from Moldova: rapid assessment, by the Special Action Programme to combat Forced Labour, ILO, March 2005. 
No. 39 Trafficking of migrant workers from Ukraine: Issues of labour and sexual exploitation, by the Special Action Programme to Combat Forced Labour, ILO, March 2005.

No. 40 El Trabajo Forzoso en la Extracción de la Madera en la Amazonía Peruana, de Eduardo Bedoya Garland y Alvaro Bedoya Silva-Santisteban, Marzo 2005

No. 41 Enganche y Servidumbre por Deudas en Bolivia, de Eduardo Bedoya Garland y Alvaro Bedoya Silva-Santisteban, Marzo 2005 